UDC 811.111:305

DOI https://doi.org/10.32838/2710-4656/2021.2-1/36

Sliepushova A. I.

Borys Grinchenko Kyiv University

\title{
AN ADULT-MINDED BABY: AN EVIL PRODIGY IN FAMILY GUY?
}

The article aims at analysis of the baby's idiolect in the animated series "Family Guy", featuring a typical American family. The study focuses on Stewie Griffin's remarks, the baby in the family, and the way his speech violates age stereotypes (about baby's talk, the way of thinking, basic needs, life goals, etc.). The conversation, discourse and corpus analyses have been used to single out Stewie's specific vocabulary - through the word list, keyword list, KWIC - he uses while communicating with his family. His speech is opposed to infant-directed speech to show the contrast between baby-mother and mother-baby discourse. The findings show that the most frequent words in the corpus are "mind", "device", "machine", "victory", "hell", "power" that reveal Stewie's genius nature and intentions of world domination. The key word combinations, that are unique in the research corpus, are mainly related to the semantic field of science ("ultra violet scanning light", "theory of molecular propulsion") and technology ("mind-control device", "time machine", "penultimate adjustment"). It contradicts age expectations based on the fact that infants of Stewie's age are supposed to speak in combinations of sounds and simple words. Moreover, Stewie's idiolect consists of words with negative semantic prosody ("contempible", "oppressive", "tyranny") that emphasize the fact that he is a villain in the animated series. The dialogues between Lois, Stewie's mother, and the baby reveal Lois's tendency to use infant-directed speech, e.g. simple sentences in forms of orders, exclamations when she talks to her son. The infant, on the contrary, violates expectations and uses advanced language, e.g. "impede", "ovarian", "uppance" that demonstrate his rebellious and rude attitude towards Lois.

Key words: idiolect, age stereotype, corpus-based analysis, animated series, Family Guy.

Problem formulation. Animated series that feature typical middle-class families represent everyday family communication. In this regard, the idiolect of family members is viewed through the prism of age, gender stereotypes and social roles within a family. Although the notion of idiolect is widely known in linguistics, there is a lack of interest in idiolect of babies and lack of empirical data on this phenomenon. Thereby the topicality of this research consists in the necessity of the investigation of baby's idiolect in the fictional family discourse.

Theoretical background. According to W. Labov, language of an individual is associated with the language of a group: "language is not a property of the individual, but of the community" [11, p. 52]. Thus, idiolect is influenced by family members as family is the first and the closest community that influences the child. The opposing position is taken by Hudson [9, p. 29] who argues that language must be in the individual rather than in the community and on this view the idiolect is based on the reality of individual usage. In this paper, the term idiolect is viewed as "the author's preferences in the selection and use of certain lexico-grammatical and nominative units that are determined by his linguistic competence, poetic skills, experience of communication and cog- nitive operations related to the process of reflection of the world by means of language" [1, p. 17].

It should be noted that language is not a stable phenomenon, consequently idiolect is dynamic in its nature too, particularly when it comes to a child's language. Babies learn to talk in stages, beginning with sounds and followed by ability to say a few words. "After 18 months, the child may be using up to 10 words and be able to assemble a couple of words to make a simple sentence such as mummy throw ball' [12]. However, the development of language is strongly interdependent with cognitive development and is influenced by social factors.

In this way, adult-directed speech is opposed to infant-directed speech also known as a baby talk $[7 ; 15]$. They differ "in linguistic aspects such as repetition, word choice, and sentence length, as well as in aspects of the speech signal itself, such as prosodic and phonemic variation" [6]. By the term baby talk is meant a special form of interaction with infants which is generally regarded as not the normal use of language [5].

So, the aim of this research is to define how the idiolect of a baby Stewie Griffin and infant-directed speech in the fictional family violate expectations based on age stereotypes. The material 
of the research are the scripts compiled from 29 episodes of the American animated series Family Guy.

The research material has been extracted from freely available scripts of American animated series Family Guy [4]. Since the research is focused on baby's idiolect, the corpus of Stewie Griffin, the baby in Family Guy, has been compiled and processed via a corpus tool Sketch Engine [13; 10]. More specifically, the corpus covers Stewie's remarks in 28 episodes (totally 25,480 words) from the first and second seasons. Also, the subcorpora of Stewie-Lois and Lois-Stewie have been compiled to analyze deviation in baby-mother and mother-baby interaction in terms of adult-directed and infant-directed speech.

Results and discussion. Family Guy is an American animated series that features the adventures of the Griffin family: an ignorant and obnoxious father Peter, a stereotypical housewife Lois, their three children Meg, Chris and Stewie, and a talking dog Brian. Family Guy has transported the format of the longest running and most popular family-centered animated series The Simpsons with its grotesque and exaggerated humour.

However, compared to a baby in The Simpsons Maggie Simpson - who does not speak, sucks on her pacifier and seems to be an innocent and cute child, Stewie Griffin is a complete opposite. This maniacal infant disobeys his parents, tends to world domination and speaks about killing his mother. Although Stewie is ignored by his family, for the reason that his parents and siblings do not understand him, he often talks to them. Furthermore, Stewie treats his teddy bear Rupert as a real person, holding conversations with it and confiding his secrets to it. The only creature that is able to understand Stewie's words is the anthropomorphic dog Brian and occasionally his older brother Chris.

According to Halliday's theory of how children learn to talk [8, p. 33], children about six to eighteen months old use language for the following functions:

- instrumental - to get what they want;

- regulatory - to regulate or control other people's behaviour;

- interactional - to interact with the people around them;

- personal - to express their awareness of themselves and of the fact that they are separate from the surrounding environment;

- heuristic - to start exploring what is around;

- imaginative - to create their own environment;

- informative - to tell somebody what has happened to children.

The above-mentioned functions are used by children until approximately the age of eighteen months - the age of Stewie Griffin - and are expressed by the combinations of sounds and single words. However, the corpus of Stewie's remarks reveals the opposite tendency.

An analysis of the wordlist illustrates that the most frequent words in Stewie's idiolect contradict general

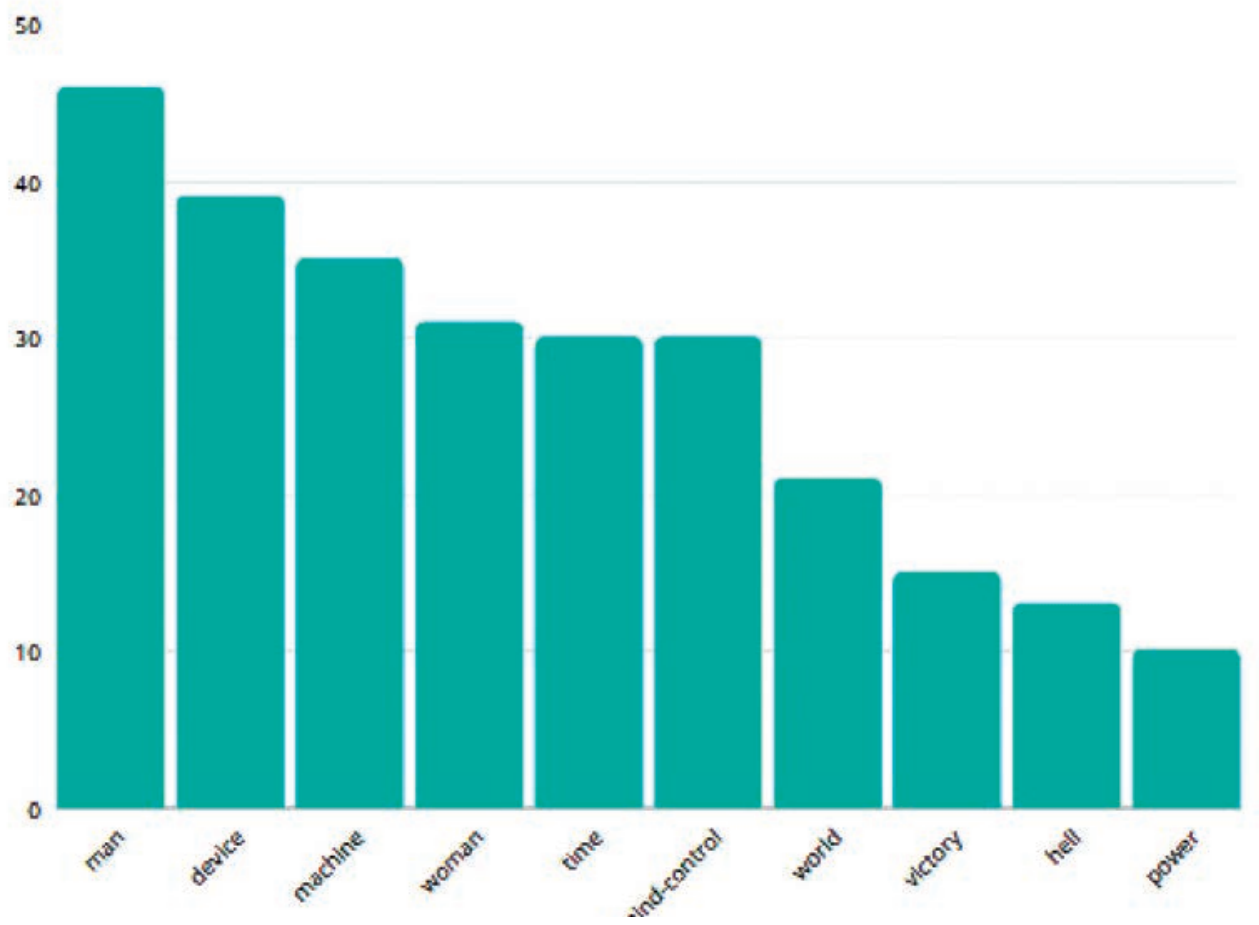

Fig. 1. Top 10 nouns in Stewie's wordlist 
expectations. Instead of the nouns like mom, water, teddy, we see an advanced vocabulary that reveals his villain and genius nature. A compound noun mindcontrol is unlikely to be used by infants, as well as words like device, machine, victory, hell, power. In fact, the wordlist of nouns reveal Stewie's areas of interest: he has constructed a mind control device to manipulate people and a time machine in an attempt to avoid the pain caused by teething while victory and power emphasize his plans on ruling the world.

Regarding keywords, that demonstrate what is unique in the corpus comparing to a reference corpus (English Web 2015), top 10 multi-word terms are:

\begin{tabular}{|ll}
\hline & Word \\
\hline 1 & mind-control device \\
\hline 2 & dramatic instrumental music \\
\hline 3 & instrumental music \\
\hline 4 & time machine \\
\hline 5 & ultra violet scanning light \\
\hline 6 & oppressive reign of matriarchal tyranny \\
\hline 7 & ovarian bastille \\
\hline 8 & contempible harpy \\
\hline 9 & theory of molecular propulsion \\
\hline 10 & penultimate adjustment \\
\hline
\end{tabular}

Fig. 2. Keywords of Stewie's remarks

The key word combinations are sophisticated and relate mainly to the semantic field of science, more specifically physics (ultra violet scanning light, theory of molecular propulsion) and technology (mind-control device, time machine, penultimate adjustment). Another tendency is the use of words with negative semantic prosody (contempible, oppressive, tyranny) that emphasize Stewie's aggressive character.

In this way the infant is represented as an adult that often expresses his anger with a swear word damn. The concordance tool, that displays the searched words in the context, shows that damn mainly collocates with you. In relation to this tendency, Stewie uses damn to express annoyance and fury towards the person he is talking to or an object, for example, broccoli that he is forced to eat.

Another significant point that shall be considered further is baby-mother discourse. When talking to her son, Lois uses above-mentioned infant-directed speech that is contrasted with adult-directed speech by a variety of properties including limited vocabulary, shorter utterances and vowel alterations [5]. This can be illustrated by the following example:

Stewie: Excellent, the mind control device is nearing completion!

Lois: Stewie, I said no toys at the table.

[takes mind control device]

Stewie: Damn you, vile woman! You've impeded my work since the day I escaped from your wretched womb.

Lois: Aw, don't pout, honey. You know, when you were born, the doctor said you were the happiest-looking baby he'd ever seen.

Stewie: But, of course! That was my victory day. The fruition of my deeply-laid plans to escape from that cursed ovarian bastille. Return the device, woman!

Lois: No toys, Stewie.

Stewie: Very well, then. Mark my words: when you least expect it, your uppance will come.

\begin{tabular}{|c|c|c|}
\hline Left context & KWIC & Right context \\
\hline ontrol device is nearing completion! $\langle/ s\rangle\langle s\rangle$ & Damn & you, vile woman! $\langle/ \mathrm{s}\rangle\langle$ s $>$ You've impeded my \\
\hline st expect it, you uppance will comel $\langle/$ s $\rangle\langle$ s $>$ & Damn & I $</ s><s>$ How do you know about the machine \\
\hline oom and the grenades blow up on him. $>$ Ah, & damn & you all! < Season 1, episode 2 I Never Met the \\
\hline :ars on me, woman! $\langle/$ s $\rangle\langle$ s $>$ Never! $\langle/$ s $\rangle\langle$ s $\rangle$ & Damn & the broccolit $\langle/ \mathrm{s}\rangle\langle\mathrm{s}\rangle$ Damn you! $\langle/ \mathrm{s}\rangle\langle\mathrm{s}\rangle$ And \\
\hline Neverl $</ \mathrm{s}\rangle\langle\mathrm{s}\rangle$ Damn the broccolil $</ \mathrm{s}\rangle\langle\mathrm{s}\rangle$ & Damn & youl $<$ /s $><$ s $>$ And damn the Wright Brothers! $<$, \\
\hline le broccoli! $</$ s $><$ s $>$ Damn you! $</$ s $><$ s $>$ And & damn & the Wright Brothers! $</$ s $><$ s $>$ Very well then. $<$ I \\
\hline$r\langle\mathrm{~s}\rangle$ Victory is...release me at oncel $\langle/ \mathrm{s}\rangle\langle\mathrm{s}\rangle$ & Damn & l $</$ s $><s>$ Thank God! $</ s><s>$ Their puerile mi \\
\hline occoli! $</ s\rangle\langle s\rangle$ Victory is mine! $</ s\rangle\langle s\rangle$ God & damn & it. $\langle/ s\rangle\langle s\rangle$ A compelling argument. $\langle/ s\rangle\langle s\rangle$ Yo \\
\hline h, God help you if I find pickles. $</ s><s>$ No, & damn & you! $</$ s $><$ s $>$ You're one of them, aren't you? $<$ \\
\hline e of my mind at oncel $\langle/ \mathrm{s}\rangle\langle\mathrm{s}\rangle \mathrm{Aghl}\langle/ \mathrm{s}\rangle\langle\mathrm{s}\rangle$ & Damn & itl $</ s><s>$ Now look here, you.... oh, my Godl « \\
\hline Det in & & \\
\hline
\end{tabular}

Fig. 3. Collocations of damn in the research corpus 
As can be seen from the extract, Lois mostly uses simple sentences in forms of orders, words Stewie, honey to communicate with her son and exclamation $a w$ to express sympathy. The infant, on the contrary, violates expectations and uses advanced language (for instance, impede, ovarian, uppance) that even a college student or average adult do not speak. Moreover, all Stewie's remarks addressed to his mother demonstrate his rebellious and rude attitude towards Lois. Instead of expected mommy, he says vile woman, insulting his mother with words your wretched womb.

The reason for Stewie's hatred towards his mother is not clear, although it might be implied that Lois makes him do what he does not want, for instance, eating vegetables. Also, Lois always unwittingly thwarts his evil schemes as it could be seen from the above-mentioned expert where she does not allow him to play his mind control device at the table, and so he desires to kill her to carry out his plans without her interference. However, the issue of Stewie's ability to speak in complete sentences is more ambiguous. According to Seth MacFarlane [14], the crea- tor of Family Guy, this aspect of Stewie's character helps make the animated series stand out. Regarding this fact, Stewie's parents who choose to ignore him resemble the way real people do with children ignoring the random noises a baby would make.

Conclusions. Considering all of these points, the idiolect of the baby Stewie Griffin in animated series Family Guy violates age expectations through the excessive amount of advanced vocabulary that could hardly be used by an infant in real life. Taking into account the semantic field of Stewie's keywords, it may be suggested that he is presented as an evil scientist who constructs devices in order to take over the world. The images of such fictional villains are usual for movies and cartoons but what is unique for Stewie is that he is malicious and destructive from his very first days, which means that the baby actually has not experienced much in his pretty short life to become so malevolent, especially towards his mother.

There is, however, a definite need for compiling a more representative corpus to analyze tendencies of baby idiolect in family discourse created in animated series.

\section{References:}

1. Безребра Н.Ю. Лінгвостилістичний та семантико-когнітивний аспекти поетики Е. Дікінсон : дис. ... канд. філол. наук : 10.02.04. Київ, 2008. 199 с.

2. Barlow M. The Individual and the Group from a Corpus Perspective. The Corpus Linguistics Discourse: In honour of Wolfgang Teubert / eds. A. Cermakova, M. Mahlberg. Amsterdam : John Benjamins, 2018. P. 164-184.

3. Dittmar N. Explorations in 'Idiolects'. Theoretical Linguistics and Grammatical Description: Papers in honour of Hans-Heinrich Lieb / R. Sackmann and M. Budde. Amsterdam : Benjamins, 1996. P. 109-128.

4. Family Guy scripts. URL: https://transcripts.fandom.com/wiki/Family_Guy (дата звернення 26.02.2021).

5. Ferguson C.A. Baby Talk in Six Languages. Center for Applied Linguistics. URL: https://anthrosource. onlinelibrary.wiley.com/doi/pdf/10.1525/aa.1964.66.suppl_3.02a00060 (дата звернення 24.02.2021).

6. Gelderloos L., Chrupała G., Alishahi A. Learning to Understand Child-directed and Adult-directed Speech. URL: https://arxiv.org/pdf/2005.02721.pdf (дата звернення 24.02.2021).

7. Golinkoff R.M., Can D.D., Soderstrom M., Hirsh-Pasek K. (Baby)Talk to Me: The Social Context of Infant-Directed Speech and Its Effects on Early Language Acquisition. Current Directions in Psychological Science. 2015. Vol. 24 (5). P. 339-344. DOI: 10.1177/0 963721415595345.

8. Halliday M.A.K. Language as social semiotic: The social interpretation of language and meaning. London : Edward Arnold, 1978. 256 p.

9. Hudson R.A. Sociolinguistics. Cambridge University Press, 1996. 279 p.

10. Kunilovskaya M., Koviazina M. Sketch Engine: A Toolbox for Linguistic Discovery. Journal of Linguistics / Jazykovedný casopis. 2018. № 68 (3). P. 503-507. DOI: 10.2478/jazcas-2018-0006.

11. Labov W. The exact description of the speech community: Short 'a' in Philadelphia. Language Change and Variation / ed. R. Fasold and D. Schiffrin. Washington D.C. : Georgetown University Press, 1989. P. 1-57.

12. Robertson S. Language Development in Children. URL: https://www.news-medical.net/health/LanguageDevelopment-in-Children.aspx (дата звернення 19.02.2021).

13. Sketch Engine. URL: https://www.sketchengine.eu/ (дата звернення 26.02.2021).

14. Stewie Griffin. Wikipedia: The Free Encyclopedia. URL: https://en.wikipedia.org/wiki/Stewie_Griffin (дата звернення 09.03.2021).

15. The ManyBabies Consortium. Quantifying sources of variability in infancy research using the infantdirected-speech preference. Advances in Methods and Practices in Psychological Science. 2020. Vol. 3 (1). P. $24-52$.

\section{СлєПУшова А. І. ДОРОСЛИЙ МАЛЮК: ЗЛИЙ ГЕНІЙ У FAMILY GUY?}

У статті проаналізовано ідіолект дитини в анімаційному серіалі «Family Guy», який розповідає про пригоди неблагонадійної американської родини. Дослідження зосереджено на репліках Стьюї Гріфіна, 
малюка в родині, та тому, як його ідіолект порушує вікові стереотипи (про мовлення дитини, спосіб мислення, основні потреби, життєві цілі тощо). Були використані дискурс і корпусний аналізи для виділення особливої лексики Стьюї-за допомогою списку найчастіше вживаних слів, списку ключових слів i ключових слів у контексті, - яку він використовує під час спілкування з родиною. Його мовлення протиставляється мовленню немовлят і розкриває різницю між дискурсом «немовля-мати» та «мати немовля». Висновки показують, що найчастіше використаними іменниками в корпусі, побудованому на репліках Стьї, $\epsilon$ «mind», «device», «тасhine», «victory», «hell», «роwеr», які розкривають геніальний характер Стьюї та його наміри щзодо світового панування. Ключові словосполучення, які є унікальними в дослідницькому корпусі, переважно семантично пов'язані зі сферою науки («ultra violet scanning light», "theory of molecular propulsion») $і$ техніки («mind-control device», "time machine», "penultimate adjustment»). Це суперечить очікуванням, пов'язаними з тим, що немовлята віку Стьюї в мовленні використовують лепетання та найпростіші слова. Більше того, ідіолект Стьюї складається зі слів із негативною семантичною просодією ("contempible», "орpressive», «tyranny»), які підкреслюють той факт, щзо він є лиходієм у мультсеріалі. Діалоги між Лоїс, матір'ю Стьюї, та немовлям виявляють схильність Лойс використовувати особливий вид дорослого мовлення, адресованого малюку, наприклад, прості речення у формі наказів, вигуків, коли вона розмовляє зі своїм сином. Немовля, навпаки, порушує очікування, пов 'язані з віковими стереотипами, і демонструє високий рівень володіння мовою, використовуючи слова, наприклад, «ітреdе», «оvarian», «иррапсе», щчо говорить про його бунтівний характер і грубе ставлення до матері.

Ключові слова: ідіолект, віковий стереотип, корпусний аналіз, анімаційний серіал, Family Guy. 